\title{
Vitamin D - hvor mye er nok, og er mer bedre for helsen?
}

\author{
Vitamin D er i vinden, og hos norske leger er det entusiasme å spore. Vitaminets vitenskapelige popularitet \\ er også udiskutabel, med nærmere 60000 treff på PubMed.
}

\author{
Magritt Brustad \\ magritt.brustad@uit.no \\ Haakon E. Meyer
}

De nordiske næringsstoffanbefalingene er nylig blitt revidert. Vi har vært deltakere i ekspertgruppen for vitamin D, oppnevnt av Nordisk ministerråd. Sammen med nordiske kolleger og etter gitte retningslinjer (1) har vi gjennomført en oppdatert systematisk kunnskapsoppsummering av vitenskapelig publisert litteratur omkring sammenhenger mellom vitamin D og helseutfall (2). Denne kunnskapsoppsummeringen har dannet grunnlaget for de reviderte anbefalingene.

For vitamin $\mathrm{D}$ er anbefalt daglig inntak økt med $33 \%$ fra de forrige nordiske anbefalingene, dvs. fra 7,5 $\mu \mathrm{g} / \mathrm{dag}$ til $10 \mu \mathrm{g} / \mathrm{dag}$. For eldre er det anbefalte inntaket økt fra $10 \mu \mathrm{g} / \mathrm{dag}$ til $20 \mu \mathrm{g} / \mathrm{dag}$. En spiseskje tran eller en porsjon laks ( $150 \mathrm{~g})$ vil gi henholdsvis $24 \mu \mathrm{g}$ og $15 \mu \mathrm{g}$ vitamin $\mathrm{D}$.

\section{Få kilder til vitamin D}

Vi får vitamin D gjennom kosten. I tillegg produseres vitaminet $i$ huden ved soleksponering. Solen er for de fleste mennesker den mest betydningsfulle kilden. For mennesker som er bosatt ved høye breddegrader er derimot kosten viktig for å få tilstrekkelig med vitamin D.

Hovedkildene til vitamin D i norsk kosthold er fet fisk, beriket smør og margarin (3), i tillegg til tran (4).

Kosten og solen gir såkalt inaktivt vitamin D, som hydroksyleres i leveren til metabolitten 25-hydroksy-vitamin D (25(OH)D). Denne hydroksyleres i nyrene til den aktive formen 1,25-dihydroksy-vitamin D. Det har vist seg at denne prosessen kan foregå $i$ en rekke andre organsystemer også (5). 25(OH)D målt i blodprøver er et anerkjent mål for vitamin D-status. Halveringstiden er noen uker (6).

\section{Vitamin D og helse}

Ekspertgruppen for vitamin D har i den systematiske kunnskapsoppsummeringen fulgt internasjonalt anerkjente metoder for systematisk litteraturgjennomgang - litteratursøk, rangering av metodisk kvalitet i aktuelle publikasjoner og oppsummeringer av funn er nøye kvalitetssikret og dokumentert gjennom en transparent arbeidsprosess.

Problemstillingene i kunnskapsoppsummeringen omfattet effekter av vitamin D-inntak på konsentrasjonen av 25(OH)D målt i blodprøver, i tillegg til forholdet mellom vitamin D og ulike helseutfall/død. Kunnskapsoppsummeringen er i hovedsak basert på allerede eksisterende systematiske oppsummeringer og randomiserte, kontrollerte studier.

Ekspertgruppen konkluderer med at det er holdepunkter for en rekke mulige positive helseeffekter av vitamin D. Imidlertid er hovedkonklusjonen til den systematiske kunnskapsoppsummeringen at det kun er tilstrekkelig vitenskapelig belegg for å fastslå at det er en beskyttende effekt av vitamin D på beinhelse, totaldødelighet og risiko for fall.

\section{Inntaksanbefalinger}

Dette er i stor grad sammenfallende med konklusjonene fra Institute of Medicines omfattende systematiske kunnskapsoppsummering fra 2009, i forbindelse med revidering av de amerikanske anbefalingene (Dietary Reference Intakes, RDI) for blant annet vitamin D (7). Institute of Medicine er et uavhengig kunnskapsbasert rådgivende organ. I de fleste studiene som ledet frem til disse konklusjonene, er det imidlertid rapportert at det er kombinasjonen av vitamin D og kalsium som har gitt effekten, ikke vitamin D alene.

Nordisk ministerråds ekspertgruppe har basert sine inntaksanbefalinger på at befolkningen bør ligge på et 25(OH)D-nivå på $>50 \mathrm{nmol} / 1$, noe som også er sammenfallende med konklusjonen fra amerikanske Institute of Medicines nyere rapport om vitamin D (8). Nivået er satt etter en totalvurdering av tilgjengelig kunnskap om D-vitaminets påvirkning på helsen.

\section{Hva er særegent for Norden og Norge?}

Norge har i europeisk sammenheng hatt et relativt høyt inntak av vitamin D. Dette er tilskrevet høyt inntak av fisk og en innarbeidet tradisjon med bruk av tran (4). Ifølge en nyere landsomfattende kostholdsundersøkelse (3) er det gjennomsnittlige inntaket av vitamin D i Norge på 6,7 $\mu \mathrm{g} / \mathrm{dag}$ for menn og 4,9 $\mu \mathrm{g} / \mathrm{dag}$ for kvinner.

Tran og andre kosttilskudd er ikke med i disse beregningene. Undersøkelse blant norske kvinner har vist at om lag $45 \%$ tar tran regelmessig (4). Det betyr at gjennomsnittinntaket i Norge ligger noe høyere enn de angitte verdiene når det tas hensyn til bidraget fra tran og kosttilskudd. Det er et høyere inntak av vitamin D i Nord-Norge enn $i$ andre deler av landet, grunnet høyere inntak av matvarer som gir vitamin D (3).

\section{$\emptyset$ kt salg av høydosetabletter med vitamin D}

Ifølge Reseptregisteret har salget av reseptbelagte vitamin D-holdige preparater i Norge økt kraftig de siste årene (9). Det har vært økning for både kvinner og menn, men bruken er høyest og økningen størst hos kvinner. Det tallmessige største bidraget $\mathrm{i}$ denne økningen kommer fra brukere av høydosepreparatet Afi D2 Forte (fig 1). Her snakker vi om en økning på drøyt 11 ganger for brukere (kvinner og menn samlet) i perioden 2004-11. Hver kapsel med Afi D2 Forte inneholder $750 \mu \mathrm{g}$ ergokalsiferol, dvs. vitamin $\mathrm{D}_{2}$.

Tar man hensyn til endring i befolkningsstørrelsen i perioden har økningen i perioden fortsatt en faktor på 11 (data ikke vist).

Det er nærliggende å anta at den kraftige økningen i bruken av høydose vitamin D-tabletter er uttrykk for vitaminets vitenskapelige popularitet og økt bevissthet hos legene om forekomsten av vitamin D-mangel i befolkningen. I tillegg vil nok entusiasmen rundt vitaminets mulige positive effekt på en rekke sykdommer også spille inn.

Fürst Medisinsk Laboratorium gjorde vitamin D-analyser i 3,5\% av samtlige innsendte prøver i 2007 , mens tilsvarende andel i 2012 var $20 \%$ (personlig meddelelse M. Buchman). Det er derfor nærliggende å tro at leger i større grad nå enn tidligere legger inn måling av vitamin D-status hos sine pasienter som rutine.

\section{Mulige helseeffekter av vitamin D}

Listen over sykdommer der det er foreslått at vitamin D har forebyggende effekt, er lang. I tillegg til skjelettsykdommer kan vi nevne demens, depresjoner, muskelsmerter, 


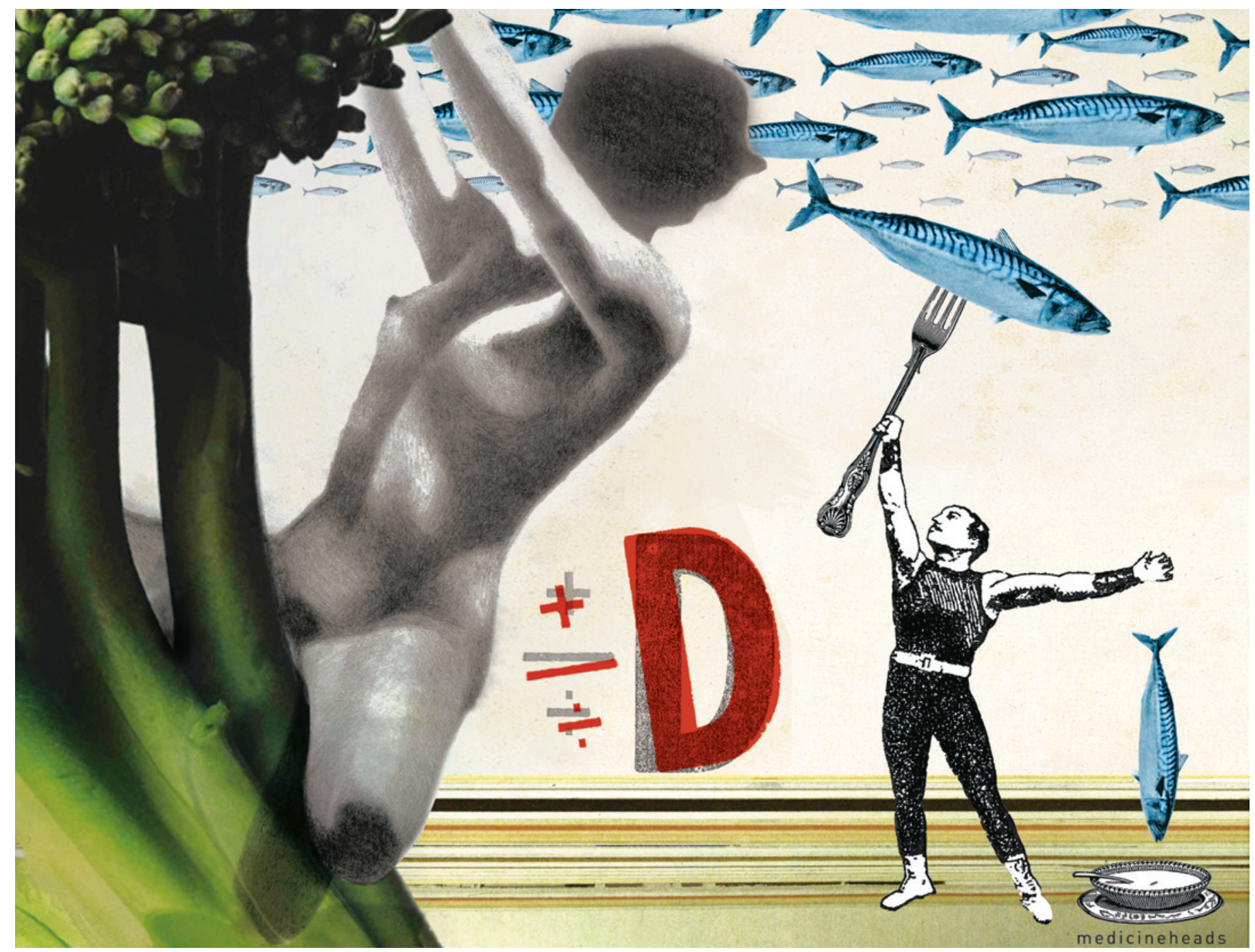

Illustrasjon () Trond Nordahl/Medicineheads

hjerte- og karsykdommer, diabetes, multippel sklerose, kreft og infeksjoner (2). Det er per dags dato ikke etablert tilstrekkelig vitenskapelig bevis for at det er en årsakssammenheng mellom vitamin D-nivå og disse tilstandene.

En utfordring knyttet til å påvise mulige sammenhenger er at vitamin $\mathrm{D}$ er assosiert med andre faktorer som er vist å ha effekt på helsen, f.eks. fysisk aktivitet og kosthold, spesielt inntak av fet fisk. Gode justeringsvariabler for disse er ikke nødvendigvis tilgjengelig i undersøkelser. Sett i lys av den økte medieoppmerksomheten og forskningsinteressen omkring vitamin $\mathrm{D}$ er det forståelig at allmennlegenes kliniske praksis er blitt påvirket og at dette har ført til at flere blodprøver sendes til 25(OH)D-analyse.

\section{Hvor bør 25(OH)D-nivået ligge?}

Essensielle næringsstoffer i gitte mengder er nødvendig for god helse. Historien har imidlertid vist at man ikke bør fristes til å tro at når små mengder er bra, er mye enda bedre. I den senere tid er det kommet flere studier som taler imot dette.

I en stor dobbeltblind, randomisert studie med eldre kvinner i Australia fant man at en årlig megadose vitamin D ga økt risiko for brudd og fall (10). U-formede sammenhenger mellom vitamin D og dødelighet

(11) har vært rapportert. Men det er fortsatt mye vi ikke vet. Nye randomiserte, kontrollerte studier hvor høyere doser av vitamin D testes med henblikk på en rekke sykdommer er på vei (12).

Grenseverdier for vitamin D-mangel uttrykt i 25(OH)D-nivåer rangerer i litteraturen gjerne fra $<25 \mathrm{nmol} / 1$ til $<75 \mathrm{nmol} / 1$, og foreslåtte optimale nivåer av vitamin $\mathrm{D}$ fra $50 \mathrm{nmol} / 1$ til $>100 \mathrm{nmol} / \mathrm{l}$ (13). Den nordiske systematiske kunnskapsoppsummeringen om vitamin $\mathrm{D}$ konkluderer at et $25(\mathrm{OH}) \mathrm{D}$-nivå på $\geq 50 \mathrm{nmol} / \mathrm{l}$ reflekterer en vitamin D-status som er tilstrekkelig høy.

Institute of Medicines konklusjon angå- ende vitamin D-status var at $50 \mathrm{nmol} / 1$ vil dekke behovet for $97,5 \%$ av befolkningen og at det ikke finnes konsistent kunnskap om at en status $\geq 50 \mathrm{nmol} / 1$ gir enda bedre helseeffekter (8).

\section{Fastsettelse av vitamin D-status}

Det har vært stilt spørsmål ved reliabiliteten av målinger av serum- eller plasma$25(\mathrm{OH}) \mathrm{D}$. En rekke studier har vist at ulike målinger i samme prøve gir meget ulike resultater (2). I en nyere svensk undersøkelse (14) ble samme prøve analysert ved tre ulike laboratorier. Resultatene viste stor diskrepans, og andelen som hadde $25(\mathrm{OH}) \mathrm{D}<50 \mathrm{nmol} / 1$ var $8 \%$ i det første laboratoriet, $22 \%$ i det andre og $43 \%$ i det tredje. De tre laboratoriene brukte ulik metode, men en norsk undersøkelse har vist at det også var forskjeller gitt samme metode (15).

Dette synliggjør utfordringer knyttet til å bruke $25(\mathrm{OH}) \mathrm{D}$ i klinisk praksis. I møte 
Antall brukere

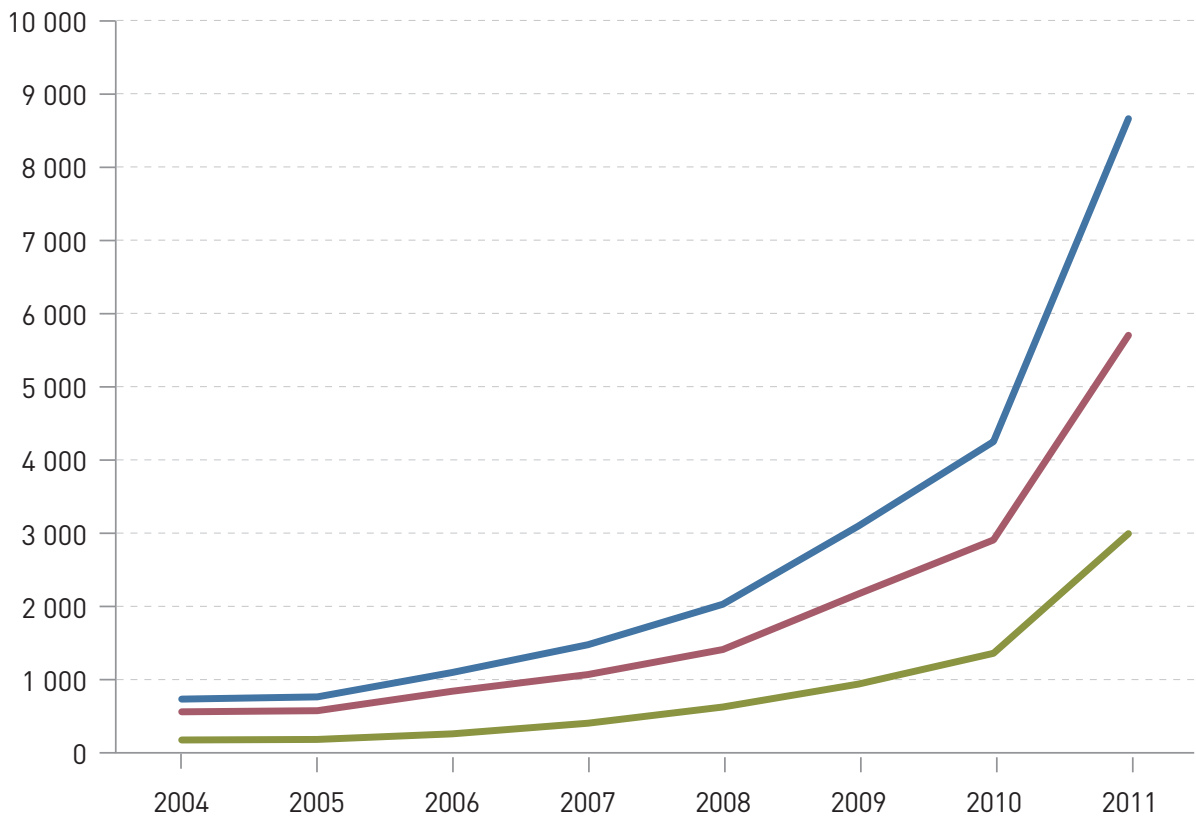

Figur 1 Antall brukere av høydosepreparatet Afi D2 Forte (ergokalsiferol) i perioden 2004-11 (9)

med den enkelte pasient vil ikke nødvendigvis én enkelt blodprøve være et presist mål for vitamin D-status, grunnet store feilmarginer i laboratorieanalysene. En anamnese over inntaket av vitamin D-rik kost og soleksponering vil hos mange kunne være vel så hensiktsmessig - forutsatt at pasienten ikke har tilstander eller bruker medikamenter som påvirker opptaket eller metabolismen av vitamin D.

\section{Oppsummering}

Forskere har hevdet at grenseverdien for $25(\mathrm{OH}) \mathrm{D}$ på $50 \mathrm{nmol} / \mathrm{l}$ er satt for lavt. Vi vil holde fast ved at det per dags dato ikke er konsensus i litteraturen som tilsier at grenseverdien bør være høyere. Bortsett fra $i$ behandlingen av pasienter med svært lave nivåer av vitamin $\mathrm{D}$ er det med utgangspunkt i dagens kunnskapsgrunnlag ikke grunn til å sette pasienter på megadoser av vitamin $\mathrm{D}$ - med tanke på mulige bieffekter dette kan ha på sikt.

U-formede sammenhenger mellom vitamin D og noen helseutfall og dødelighet har vært rapportert. Usikkerheten rundt laboratoriemål for vitamin D-status tilsier at fastsettelsen av dette og eventuelt behov for tilskudd basert på en blodprøve kan være problematisk.

Hensikten med næringsstoffanbefalinger er å sikre god ernæringsstatus i befolkningen. Ved regelmessig bruk av tran og inntak av fet fisk vil det daglige D-vitaminbehovet være dekket for de fleste.
Vi takker førsteamanuensis Kjersti Bakken, Institutt for samfunnsmedisin, Universitetet i TromsøNorges arktiske universitet, for god hjelp med å tolke tallene fra Reseptregisteret.

\section{Magritt Brustad (f. 1970)}

er professor dr.scient., ernæringsfysiolog og instituttleder ved Institutt for samfunnsmedisin, Universitetet i Troms $\varnothing$ - Norges arktiske universitet. Hun var medlem i Nasjonalt råd for ernæring i perioden 2006-12 og i den nordiske ekspertgruppen som utarbeidet en systematisk kunnskapsoppsummering om vitamin D og helse i forbindelse med 5. revisjon av de nordiske næringsstoffanbefalingene.

Forfatter har fylt ut ICMJE-skjemaet og oppgir ingen interessekonflikter.

\section{Haakon E. Meyer (f. 1959)}

er professor i epidemiologi og forebyggende medisin ved Universitetet i Oslo og overlege ved Divisjon for epidemiologi, Nasjonalt folkehelseinstitutt. Han var leder av Nasjonalt råd for ernæring i perioden 2006-12 og medlem i den nordiske ekspertgruppen som utarbeidet en systematisk kunnskapsoppsummering om vitamin $\mathrm{D}$ og helse i forbindelse med 5. revisjon av de nordiske næringsstoffanbefalingene. Forfatter har fylt ut ICMJE-skjemaet og oppgir følgende interessekonflikter: Han har deltatt i en studie støttet av Fürst Medisinsk Laboratorium og Nycomed.
Litteratur

1. NORDEN - Nordic Council of Ministers. SLR guide: A guide for conducting systematic literature reviews for the 5th edition of the Nordic Nutrition recommendations. www.slv.se/en-gb/ Startpage-NNR/NNR5-News/A-guide-forconducting-Systematic-Literature-Reviewsfor-the-5th-edition-of-the-Nordic-NutritionRecommendations/ (4.2.2014).

2. Lamberg-Allardt C, Brustad M, Meyer HE et al. Vitamin D - a systematic literature review for the 5 th edition of the Nordic Nutrition Recommendations. Food Nutr Res 2013; 57

3. Totland TH, Melnæs BK, Lundberg-Hallen $\mathrm{N}$ et al. Nordkost 3. En landsomfattende kostholdsundersøkelse blant menn og kvinner i Norge i alderen 18-70 år, 2010-11. Oslo: Helsedirektoratet, 2012.

4. Brustad M, Braaten T, Lund E. Predictors for codliver oil supplement use-the Norwegian Women and Cancer Study. Eur J Clin Nutr 2004; 58 : 128-36.

5. Holick MF. Vitamin D: A millenium perspective. J Cell Biochem 2003; 88: 296-307

6. Jones $G$. Pharmacokinetics of vitamin D toxicity. Am J Clin Nutr 2008; 88: 582S-6S.

7. Chung M, Balk EM, Brendel $M$ et al. Vitamin D and calcium: a systematic review of health outcomes. Evid Rep Technol Assess (Full Rep) 2009; nr. 183 $1-420$.

8. Ross AC, Manson JE, Abrams SA et al. The 2011 report on dietary reference intakes for calcium and vitamin D from the Institute of Medicine: what clinicians need to know. J Clin Endocrinol Metab 2011; 96: 53-8.

9. Folkehelseinstituttet. Reseptregisteret. www.reseptregisteret.no/Prevalens.aspx (19.10.2012).

10. Sanders KM, Stuart AL, Williamson EJ et al. Annual high-dose oral vitamin D and falls and fractures in older women: a randomized controlled trial. JAMA 2010; 303: 1815-22.

11. Michaëlsson K, Baron JA, Snellman G et al. Plasma vitamin $D$ and mortality in older men a community-based prospective cohort study. Am J Clin Nutr 2010: 92: 841-8.

12. Kupferschmidt K. Uncertain verdict as vitamin D goes on trial. Science 2012; 337: 1476-8

13. Rosen CJ, Taylor CL. Common misconceptions about vitamin D-implications for clinicians. Nat Rev Endocrinol 2013; 9: 434-8.

14. Snellman G, Melhus H, Gedeborg R et al. Deter mining vitamin $D$ status: a comparison between commercially available assays. PLoS ONE 2010; 5: e11555.

15. Grimnes G, Almaas B, Eggen AE et al. Effect of smoking on the serum levels of 25-hydroxyvitamin $\mathrm{D}$ depends on the assay employed. Eur J Endocrinol 2010; 163: 339-48.

Mottatt 22.11. 2013, første revisjon innsendt 16.1. 2014, godkjent 4.2. 2014. Redaktør: Matilde Risopatron Berg. 